\title{
TINGKAT PENGETAHUAN IBU PRIMIGRAVIDA BERHUBUNGAN DENGAN KECEMASAN RENCANA SECTIO CAESAREA
}

\author{
${ }^{1}$ Nindya Saputri, ${ }^{2}$ Sondang R. Sianturi \\ ${ }^{1}$ Perawat RS Mitra Keluarga, Jakarta \\ ${ }^{2}$ STIK Sint Carolus, Jakarta Pusat, 10440, Indonesia, sondangrsianturi@gmail.com
}

\begin{abstract}
ABSTRAK
Latar belakang: Setiap ibu hamil menginginkan dapat melahirkan secara normal, tetapi dalam kondisi tertentu harus dilakukan persalinan secara Sectio Caesarea. Proses persalinan Sectio Caesarea ini akan menimbulkan kecemasan dan rasa takut karena kurangnya informasi yang didapat oleh ibu mengenai tindakan sectio caesarea yang akan dilakukan.
\end{abstract}

Tujuan: untuk mengetahui hubungan tingkat pengetahuan dengan tingkat kecemasan ibu primigravida dengan rencana SC.

Metode: Jenis penelitian ini adalah penelitian korelasional dengan desain cross sectional yang menggunakan analisis uji Kendal Tau. Penelitian ini dilakukan di RS X di Bekasi. Teknik pengambilan sampel adalah purposive sampling yaitu 30 orang ibu primigravida dengan hamil aterm, tidak ada komplikasi pada ibu dan akan melakukan tindakan section caesarea.

Hasil: Hasil analisis univariat yaitu 96,7\% responden berusia 20-35 tahun, 53,3\% memiliki latar belakang pendidikan perguruan tinggi, 46,6\% sebagai wiraswasta, 36,7\% responden memiliki pengetahuan cukup dengan 63,3\% memiliki dukungan keluarga, 70\% mendapat dukungan dari petugas kesehatan, $40 \%$ responden mengalami kecemasan sedang dan 20\% kecemasan berat. Berdasarkan hasil analisis bivariate didapatkan hasil ada hubungan antara pendidikan (pvalue 0.015), pekerjaan (pvalue 0.019), dukungan keluarga (pvalue 0.016), dukungan petugas kesehatan (pvalue 0.001) terhadap kecemasan,dan ada hubungan pengetahuan dan kecemasan responden dengan pvalue 0.002. Tetapi tidak terdapat hubungan antara usia dengan kecemasan responden dengan pvalue 0.297 .

Simpulan: Dari hasil uji statistic pada penelitian ini didapatkan data ada hubungan yang significant antara tingkat pengetahuan responden dengan kecemasan yang dialami dalam menghadapi persalinan section caesarea.

Kata kunci: Tingkat Pengetahuan, Tingkat Kecemasan, Primigravida 


\begin{abstract}
Background: Every pregnant women desire to normal childbirth, but under certain conditions it is necessary to have a Caesarean section delivery. The process of giving birth to a Caesarean section will cause anxiety and fear because of the lack of information obtained by the mother regarding the section caesarean procedure to be performed.
\end{abstract}

Objective: The purpose is to describe the relationship between knowledge level and anxiety level of primigravida mothers with caesarean section plan

Methods: Type of this research is correlational study with a cross sectional design using the Kendal tau test analysis. This research was conducted at $\mathrm{X}$ hospital in Bekasi. The sampling technique was purposive sampling, with 30 primigravida mothers with term pregnancy, no complications to the mother and will perform a caesarean section.

Result: The results of univariate analysis are $96.7 \%$ of respondents aged 20-35 years, $53.3 \%$ have a college education background, $46.6 \%$ as enterpreneurs, $36.7 \%$ of respondents have sufficient knowledge with $63.3 \%$ have support family, $70 \%$ received support from health workers, and $40 \%$ of respondents' experienced moderate anxiety and $20 \%$ had severe anxiety. Based on the results of the bivariate analysis, it was found that there was a relationship between education (pvalue 0.015), work (pvalue 0.019), family support (pvalue 0.016), and support from health workers (pvalue 0.001) on anxiety, and there was a relationship between knowledge and anxiety of respondents with pvalue 0.002 . But there is no relationship between age and respondent anxiety with a pvalue of 0.297 .

Conclusion: From the results of statistical tests in this study, it was found that there was a significant relationship between the respondent's level of knowledge and anxiety experienced in dealing with caesarean section delivery.

Keywords: Anxiety level, Knowledge level, Primigravida

\section{PENDAHULUAN}

Kehamilan sebagai suatu keadaan fisiologis dapat diikuti oleh proses patologis yang mengancam keadaan ibu dan janin, sehingga akan menimbulkan kecemasan pada ibu hamil. Mulyati menyatakan bahwa terdapat 20 dari 100 ibu hamil mengalami gangguan kehamilan, persalinan atau masa nifas, dimana pada saat Antenatal Care, ibu hamil dapat mengetahui berbagi resiko dan komplikasi kehamilan yang dialaminya. Sehingga ibu hamil dapat mengetahui perkembangan dan komplikasi penyakit yang akan terjadi 
pada saat kehamilan dan janinnya (Mulyawati. Dkk, 2012).

Persalinan dapat dilakukan dengan dua cara yaitu pertama pervaginam dimana keluarnya hasil konsepsi melewati jalan lahir yang dapat dilakukan tanpa bantuan alat dan dengan bantuan alat (obsetrik operatif). Cara persalinan yang kedua yaitu dengan Sectio Caesarea dimana janin dilahirkan melalui insisi pada dinding perut dan dinding rahim dengan syarat rahim dalam keadaan utuh dan berat janin diatas 500 gram) (Green, 2012). Setiap ibu hamil menginginkan agar dapat melahirkan secara normal. Tetapi ada kondisi tertentu yang dapat mempengaruhi proses melahirkan sehingga harus dilakukan operasi sectio caesarea yaitu dari faktor janin dan factor ibu. Kondisi yang dipengaruhi dari factor janin terdiri dari bayi terlalu besar, kelainan letak, ancaman gawat janin, janin abnormal, kelainan tali pusat dan bayi kembar. Kondisi yang dipengaruhi dari dari faktor ibu yaitu keadaan panggul, kelainan kontraksi rahim, ketuban pecah dini dan pre eklamsia (Hutabalian, 2011).

Berdasarkan data dari World Health Organization (WHO, 2013) menetapkan standar rata - rata sectio caesarea di sebuah negara adalah sekitar 5\% per 1000 kelahiran di dunia. Beberapa penelitian menyatakan bahwa pada 15 negara di dunia terdapat $40 \%$ bayi lahir menggunakan cara operasi section caesarea dan persentase tertinggi ada d Republik Dominika yaitu 58,1\%. Di Indonesia persalinan metode sectio caesarea bukan merupakan hal yang baru lagi. Hal ini terbukti dengan meningkatnya angka sectio caesarea dalam kurun waktu 20 tahun terakhir di Indonesia. Angka kejadian section caesarea di Indonesia menurut survey Nasional pada tahun 2013 adalah $+/-1.200 .000$ dari +/-5.690.000 persalinan atau sekitar $24,8 \%$ dari seluruh persalinan (Depkes,2012)

Kasus Obgyn, khususnya sectio caesarea menempati urutan kedua dari kasus - kasus bedah lainnya di Rumah Sakit X di Bekasi. Pada tahun 2017 bulan Januari sampai bulan Juni untuk tindakan sectio caesarea rata - rata 100 klien / bulan tidak hanya pada primigravida. Pada 6 bulan pasien pra operasi sectio caesarea sebanyak 749 klien di Rumah Sakit X di Bekasi. Untuk tindakan sectio caesarea pada primi gravida bulan Januari - Juni 2017 sebanyak \pm 125 klien. Berdasarkan hasil wawancara ibu 
primigravida tentang kecemasan pada operasi sectio caesarea mengungkapkan bahwa ada rasa cemas dan takut karena kehamilan anak pertama dan belum pengalaman. Disisi lain Ibu hamil hanya sedikit mengetahui tentang informasi pra bedah sectio caesarea.

Respon psikologi seorang tidak hanya akan mempengaruhi tingkat pengetahuan tentang pre operasi sectio caesarea dengan tingkat kecemasan. Para ibu hamil yang belum dapat pengetahuan tentang pre operasi sectio caesarea mungkin cemas dan dapat bertanya - tanya bagaimana resiko selanjutnya tentang post operasi sectio caesarea. Hal ini dinyatakan dalam journal yang mengatakan bahwa ibu Jenis penelitian ini adalah penelitian analitik korelational yaitu suatu penelitian yang mencoba menggali bagaimana dan mengapa fenomena kesehatan itu terjadi, kemudian melakukan analisa dinamika korelasi antara fenomena atau antar faktor resiko dengan faktor efek. Populasi pada peneliti mengambil klien yang akan melakukan tindakan sectio caesarea pada ibu primigravida di ruang Maternitas dan Kamar primigravida merasakan ketakutan ketika membayangkan proses persalinan kelak karena tidak berpengalaman. Primigravida ini rata - rata memiliki kesamaan dalam pikiran mereka bahwa melahirkan itu merupakan proses yang menakutkan, menyeramkan dan menyakitkan, takut tidak menjadi ibu yang baik bagi bayi dan ketakutan bayi lahir cacat (Novitasari, 2013). Respon fisiologis dengan tingkat kecemasan terjadi antara gejala atau mekanisme koping yang dikembangkan sebagai pertahanan terhadap kecemasan (Stuart, 2016).

\section{METODE PENELITIAN}

Bersalin Rumah Sakit X, dengan koresponden berjumlah 30 orang dalam 1 bulan. Sample pada penelitian ini diambil dengan teknik purposive sampling. Sample pada penelitian ini diambil dari responden yang akan Penelitian ini menggunakan kuesioner pengetahuan dan kecemasan yang sudah dilakukan uji validitas dan reliabilitas yaitu dengan nilai cronbach alpha 0,751 dan $r$ table 0,374. Kriteria responden penelitian adalah pasien 
yang enjalani sectio caesarea dengan

kriteria responden yaitu primigravida, responden baru masuk ke ruang rawat dan akan dilakukan sectio caesarea keesokan harinya.

\section{HASIL DAN PEMBAHASAN}

Tabel 1

Distribusi Frekuensi Karakteristik Responden, Pengetahuan, Dukungan keluarga, Dukungan Petugas Kesehatan dan Tingkat Kecemasan Responden

\begin{tabular}{|c|c|c|}
\hline \multirow{2}{*}{\multicolumn{3}{|c|}{ Percent $(\%)$}} \\
\hline & & \\
\hline$<20$ tahun & 1 & 3,3 \\
\hline 20-35 tahun & 29 & 96,7 \\
\hline \multicolumn{3}{|l|}{ Pendidikan } \\
\hline SMP & 0 & 0.0 \\
\hline SMA & 14 & 46.7 \\
\hline Perguruan Tinggi & 16 & 53.3 \\
\hline \multicolumn{3}{|l|}{ Pekerjaan } \\
\hline IRT & 13 & 43.3 \\
\hline PNS & 3 & 10.0 \\
\hline Wiraswasta & 14 & 46.6 \\
\hline \multicolumn{3}{|l|}{ Pengetahuan } \\
\hline Baik & 9 & 30.0 \\
\hline Cukup & 11 & 36.7 \\
\hline Kurang & 10 & 33.3 \\
\hline \multicolumn{3}{|l|}{ Dukungan keluarga } \\
\hline Tidak ada & 11 & 36.7 \\
\hline Ada & 19 & 63.3 \\
\hline \multicolumn{3}{|l|}{ Dukungan petugas } \\
\hline kesehatan & 21 & 70 \\
\hline Ada & 9 & 30 \\
\hline \multicolumn{3}{|l|}{ Tidak ada } \\
\hline \multicolumn{3}{|l|}{ Tingkat kecemasan } \\
\hline Tidak ada & 1 & 3.3 \\
\hline Ringan & 10 & 33.3 \\
\hline Sedang & 12 & 40.0 \\
\hline Berat & 6 & 20.0 \\
\hline Panik & 1 & 3.3 \\
\hline
\end{tabular}

Dari Tabel 1 dapat diketahui bahwa sebagian besar responden berusia 20-35 tahun sebesar 96,7\% dengan tingkat pendidikan $53,3 \%$, dan $46,6 \%$ dengan pekerjaan wiraswasta. Selain itu terdapat data $36,7 \%$ responden memiliki tingkat pengetahuan yang cukup, 63,3\% memiliki dukungan dari keluarga dan $70 \%$ memiliki dukungan dari petugas kesehatan. Ibu primigravida dengan rencana sectio caesarea di Rumah Sakit $\mathrm{X}$ memiliki tingkat kecemasan sedang yaitu sebanyak $40.0 \%$ 
responden, dan tingkat kecemasan ringan sebanyak $33.3 \%$ responden, tetapi ada juga responden yang memiliki tingkat kecemasan berat sebanyak $20.0 \%$ responden dan panik ada $3.3 \%$ responden.

Zamriati (2013) tentang faktor - faktor penyebab kecemasan ibu dalam menghadapi persalinan yaitu dari usia, paritas dan pengalam traumatis. Ada beberapa faktor yang mempengaruhi ibu hamil dalam

merespon kecemasan yaitu konflik diri terdiri dari konflik intern antara ketakutan terhadap suatu kejadian atau peristiwa, psikologis ibu, keluarga ibu hamil. Data wawancara dengan responden bahwa sebagian responden panik akan operasi sectio caesarea dan membuat responden cemas akan tindakan operasi sectio caesarea yang sebagian besar mereka mengambil kuesioner kecemasan memilihpilihan yang kedua.

Table 2

Hubungan antara usia dengan tingkat kecemasan Ibu primigravida dengan rencana sectio caesarea

\begin{tabular}{|c|c|c|c|c|c|c|c|}
\hline \multirow{3}{*}{ Usia (tahun) } & \multicolumn{5}{|c|}{ Tingkat kecemasan } & \multirow{3}{*}{ Total } & \multirow{3}{*}{$\mathrm{P}$} \\
\hline & & & & & & & \\
\hline & Tidak ada & Ringan & Sedang & Berat & Panik & & \\
\hline \multirow[t]{2}{*}{$<20$} & 0 & 0 & 0 & 1 & 0 & 1 & \multirow{5}{*}{.297} \\
\hline & $0.0 \%$ & $0.0 \%$ & $0.0 \%$ & 100.0 & $0.0 \%$ & $100.0 \%$ & \\
\hline \multirow[t]{2}{*}{ 20-35 } & 1 & 10 & 11 & 6 & 1 & 29 & \\
\hline & $3.4 \%$ & $34.5 \%$ & $37.9 \%$ & $20.7 \%$ & $3.4 \%$ & $100.0 \%$ & \\
\hline Total & 1 & 10 & 11 & 7 & 1 & 30 & \\
\hline
\end{tabular}

Dari hasil uji statistik Kendal tau c dengan tingkat kepercayaan 95\%, di dapatkan hasil $p$ value sebesar 0.297. Hal ini berarti tidak ada hubungan yang antara usia dengan tingkat kecemasan Ibu primigravida dengan sectio caesarea di Rumah Sakit X Bekasi tahun 2017. Penelitian dikuatkan oleh penelitian Rahmi (2010), di RSUP Padang, yang menyatakan bahwa tidak ada hubungan antara usia dengan tingkat kecemasan Ibu primigravida dengan sectio caesarea, dimana $p$ valuenya $=$ 0.215 .

Menurut Manuaba (2010), secara psikologis, pada Ibu hamil yang berusia < 20 tahun, mempunyai kesiapan mental yang masih sangat kurang, sehingga ketika ibu hamil 
tersebut akan menghadapi persalinan, banyak masalah psikologis yang muncul. Berdasarkan hasil penelitian, peneliti berpendapat bahwa usia tidak berpengaruh terhadap tingkat kecemasan ibu primigravida dengan sectio caesarea. Hal ini berkaitan dengan pengalaman seoorang ibu pada saat menghadapi persalinan. Di rumah sakit sering juga dijumpai, usia ibu < 20 maupun $>20$ tahun, masih megalami kecemasan.

Tabel 3

Hubungan antara pendidikan dengan tingkat kecemasan

\begin{tabular}{|c|c|c|c|c|c|c|c|}
\hline \multirow{3}{*}{ Pendidikan } & \multicolumn{5}{|c|}{ Tingkat kecemasan } & \multirow{3}{*}{ Total } & \multirow{3}{*}{$\mathrm{P}$} \\
\hline & & & & & & & \\
\hline & Tdk ada & Ringan & Sedang & Berat & Panik & & \\
\hline \multirow[t]{2}{*}{ SMA } & 1 & 2 & 4 & 6 & 1 & 14 & \multirow{6}{*}{.015} \\
\hline & $7.1 \%$ & $14.3 \%$ & $28.6 \%$ & $42.9 \%$ & $7.1 \%$ & $100.0 \%$ & \\
\hline Perguruan & 0 & 8 & 7 & 1 & 0 & 16 & \\
\hline Tinggi & $0.0 \%$ & $50.0 \%$ & $43.8 \%$ & $6.3 \%$ & $0.0 \%$ & $100.0 \%$ & \\
\hline \multirow[t]{2}{*}{ Total } & 1 & 12 & 11 & 7 & 1 & 30 & \\
\hline & $3.3 \%$ & $33.3 \%$ & $36.7 \%$ & $23.3 \%$ & $3.3 \%$ & $100.0 \%$ & \\
\hline
\end{tabular}

Hasil penelitian ini sejalan dengan penelitian Reska Handayani (2012) di Puskesmas Padang, yang mengemukakan bahwa ada hubungan antara pendidikan dengan tingkat kecemasan Ibu primigravida, dimana $p$ valuenya $=0.05$. Penelitian ini juga dikuatkan oleh penelitian Rahmi (2010), di RSUP Padang, yang menyatakan bahwa ada hubungan antara pendidikan dengan tingkat kecemasan Ibu primigravida dengan sectio caesarea, dimana $p$ valuenya $=$ 0.03 .

Tingkat pendidikan formal merupakan dasar pengetahuan intelektual yang dimiliki seseorang. Hal ini erat kaitannya dengan pengetahuan, karena semakin tinggi pendidikan semakin besar kemampuan menyerap dan menerima informasi. Hal ini dapat menambah atau mengembangkan wawasan menjadi semakin luas (Rinaldi, 2013). Status pengetahuan yang rendah pada seseorang akan menyebabkan orang tersebut mengalami kecemasan, karena semakin tinggi tingkat pengetahuan akan semakin mudah berfikir rasional dalam menguraikan masalah (Stuart, 2007). 
Tabel 4

Hubungan antara pekerjaan dengan tingkat kecemasan

\begin{tabular}{|c|c|c|c|c|c|c|c|}
\hline \multirow{3}{*}{ Pekerjaan } & \multicolumn{5}{|c|}{ Tingkat kecemasan } & \multirow{3}{*}{ Total } & \multirow{3}{*}{$\mathrm{P}$} \\
\hline & & & & & & & \\
\hline & Tdk ada & Ringan & Sedang & Berat & Panik & & \\
\hline IRT & $\begin{array}{c}0 \\
0.0 \%\end{array}$ & $\begin{array}{c}3 \\
23.1 \%\end{array}$ & $\begin{array}{c}3 \\
23.1 \%\end{array}$ & $\begin{array}{c}6 \\
46.2 \%\end{array}$ & $\begin{array}{c}1 \\
7.7 \%\end{array}$ & $\begin{array}{c}13 \\
100.0 \%\end{array}$ & \\
\hline PNS & $\begin{array}{c}0 \\
0.0\end{array}$ & $\begin{array}{c}2 \\
66.7 \%\end{array}$ & $\begin{array}{c}1 \\
33.7 \%\end{array}$ & $\begin{array}{c}0 \\
0.0 \%\end{array}$ & $\begin{array}{c}0 \\
0.0 \%\end{array}$ & $\begin{array}{c}3 \\
100.0 \%\end{array}$ & .019 \\
\hline swasta & $\begin{array}{c}1 \\
7.1 \%\end{array}$ & $\begin{array}{c}5 \\
35.7 \%\end{array}$ & $\begin{array}{c}7 \\
50.0 \%\end{array}$ & $\begin{array}{c}1 \\
7.1 \%\end{array}$ & $\begin{array}{c}0 \\
0.0 \%\end{array}$ & $\begin{array}{c}14 \\
100.0 \%\end{array}$ & \\
\hline Total & $\begin{array}{c}1 \\
3.3 \% \\
\end{array}$ & $\begin{array}{c}10 \\
33 \%\end{array}$ & $\begin{array}{c}11 \\
36.7 \% \\
\end{array}$ & $\begin{array}{c}7 \\
23.3 \% \\
\end{array}$ & $\begin{array}{c}1 \\
3.3 \% \\
\end{array}$ & $\begin{array}{c}30 \\
100.0 \% \\
\end{array}$ & \\
\hline
\end{tabular}

Hasil penelitian ini sejalan dengan penelitian Yanita Astuti (2012) di RSUD Pasar Rebo. yang mengemukakan bahwa ada hubungan antara pekerjaan dengan tingkat kecemasan Ibu primigravida, dimana $p$ valuenya $=0.022$. Berdasarkan penelitian diatas, bahwa ibu primigravida yang memiliki pekerjaan, cenderung lebih beresiko terkena sesuatu penyakit dibanding dengan ibu rumah tangga. Oleh karena itu, orang tersebut akan lebih sering memanfaatkan pelayanan kesehatan.

Tabel 5

Hubungan antara dukungan keluarga dengan tingkat kecemasan

\begin{tabular}{|c|c|c|c|c|c|c|c|}
\hline \multirow{2}{*}{$\begin{array}{l}\text { Dukungan } \\
\text { keluarga }\end{array}$} & \multicolumn{5}{|c|}{ Tingkat kecemasan } & \multirow{2}{*}{ Total } & \multirow{2}{*}{$\mathrm{P}$} \\
\hline & Tdk ada & Ringan & Sedang & Berat & Panik & & \\
\hline \multirow[t]{2}{*}{ Tidak ada } & 0 & 1 & 4 & 5 & 1 & 11 & \\
\hline & & $9.1 \%$ & $36.4 \%$ & $45.5 \%$ & 9.1 & $100.0 \%$ & \\
\hline \multirow[t]{2}{*}{ Ada } & 2 & 10 & 6 & 1 & 0 & 19 & \\
\hline & 10.5 & $52.6 \%$ & $31.6 \%$ & $5.3 \%$ & 0.0 & 100.0 & .016 \\
\hline \multirow[t]{2}{*}{ Total } & 2 & 11 & 10 & 6 & 1 & 30 & \\
\hline & 6.7 & $36.7 \%$ & $33.3 \%$ & $20.0 \%$ & 3.3 & $100.0 \%$ & \\
\hline
\end{tabular}

Hasil penelitian ini sejalan dengan penelitian Reska Handayani (2012) di Puskesmas Padang, yang menyatakan bahwa ada hubungan antara pengetahuan dengan tingkat kecemasan Ibu primigravida, dimana $p$ 
valuenya $=0.000$. Penelitian ini juga dikuatkan oleh penelitian Pevi Primasnia (2013), di Rumah Bersalin Kota Ungaran, yang menyatakan bahwa ada hubungan antara dukungan suami dengan tingkat kecemasan ibu primigravida dengan sectio caesarea, dimana $p$ valuenya $=0.007$.

Dorongan moril maupun materil yang diberikan oleh anggota keluarga untuk mewujudkan suatu rencana merupakan hal yang dapat memberikan keuntungan emosional atau pengaruh tingkah laku seseorang. Menurut Friedman (2011) dukungan keluarga berhubungan dengan kesehatan emosi seseorang, dimana dukungan informasi, penilaian atau bimbingan, pertolongan dan dukungan emosional. Dukungan keluarga merupakan semangat yang diberikan oleh keluarga terhadap anggota individunya. Individu tersebut percaya bahwa dukungan keluarga dapat membantu menghadapi suatu masalah

Tabel 6

Hubungan antara dukungan petugas kesehatan dengan tingkat kecemasan

\begin{tabular}{|c|c|c|c|c|c|c|c|}
\hline \multirow{2}{*}{$\begin{array}{l}\text { Dukungan petugas } \\
\text { kesehatan }\end{array}$} & \multicolumn{5}{|c|}{ Tingkat kecemasan } & \multirow{2}{*}{ Total } & \multirow{2}{*}{ pvalue } \\
\hline & Tidak ada & Ringan & Sedang & Berat & Panik & & \\
\hline \multirow[t]{2}{*}{ Ada } & 1 & 10 & 9 & 1 & 0 & 21 & .001 \\
\hline & $4.8 \%$ & $47.6 \%$ & $42.9 \%$ & $4.8 \%$ & $4.8 \%$ & $100.0 \%$ & \\
\hline \multirow[t]{2}{*}{ Tidak ada } & 0 & 0 & 2 & 6 & 1 & 9 & \\
\hline & $0.0 \%$ & $0.0 \%$ & $22.2 \%$ & $66.7 \%$ & $11.1 \%$ & $100.0 \%$ & \\
\hline \multirow[t]{2}{*}{ Total } & 1 & 10 & 11 & 7 & 1 & 30 & \\
\hline & $3.3 \%$ & $33.3 \%$ & $36.7 \%$ & $23.3 \%$ & $3.3 \%$ & $100.0 \%$ & \\
\hline
\end{tabular}

Hasil penelitian ini sejalan dengan penelitian Nindy Gustianti (2011) di RSUD Anutapura Palu, yang mengemukakan bahwa ada hubungan antara dukungan petugas kesehatan dengan tingkat kecemasan Ibu primigravida, dimana $p$ valuenya $=$ 0.023. Penelitian ini juga dikuatkan oleh penelitian Sucipto (2010) di Puskesmas Bantul, yang menyatakan bahwa ada hubungan antara dukungan petugas kesehatan dengan tingkat kecemasan ibu primigravida dengan sectio caesarea, dimana $p$ valuenya $=$ 0.016. Menurut Margiyati (2013), penolong persalinan sebagai pemberi asuhan kesehatan harus dapat mengenali gejala kecemasan dan cara mengurangi kecemasan ibu hamil dengan memberikan penjelasan mengenai kehamilan, persalinan, kecemasan serta efeknya bagi ibu dan 
janin pada saat ante natal care (ANC). Pada asuhan sayang ibu, petugas kesehatan harus memberikan dukungan psikologis dengan cara meyakinkan ibu bahwa operasi merupakan proses yang dapat dilalui oleh semua orang. Ibu yang melakukan pemeriksaan secara teratur akan meningkatkan pemahaman ibu tentang kehamilan, persalian dan nifas,

Tabel sehingga ibu hamil akan mampu mengurangi kecemasan yang dialami.

Hubungan Tingkat Pengetahuan dan Tingkat Kecemasan

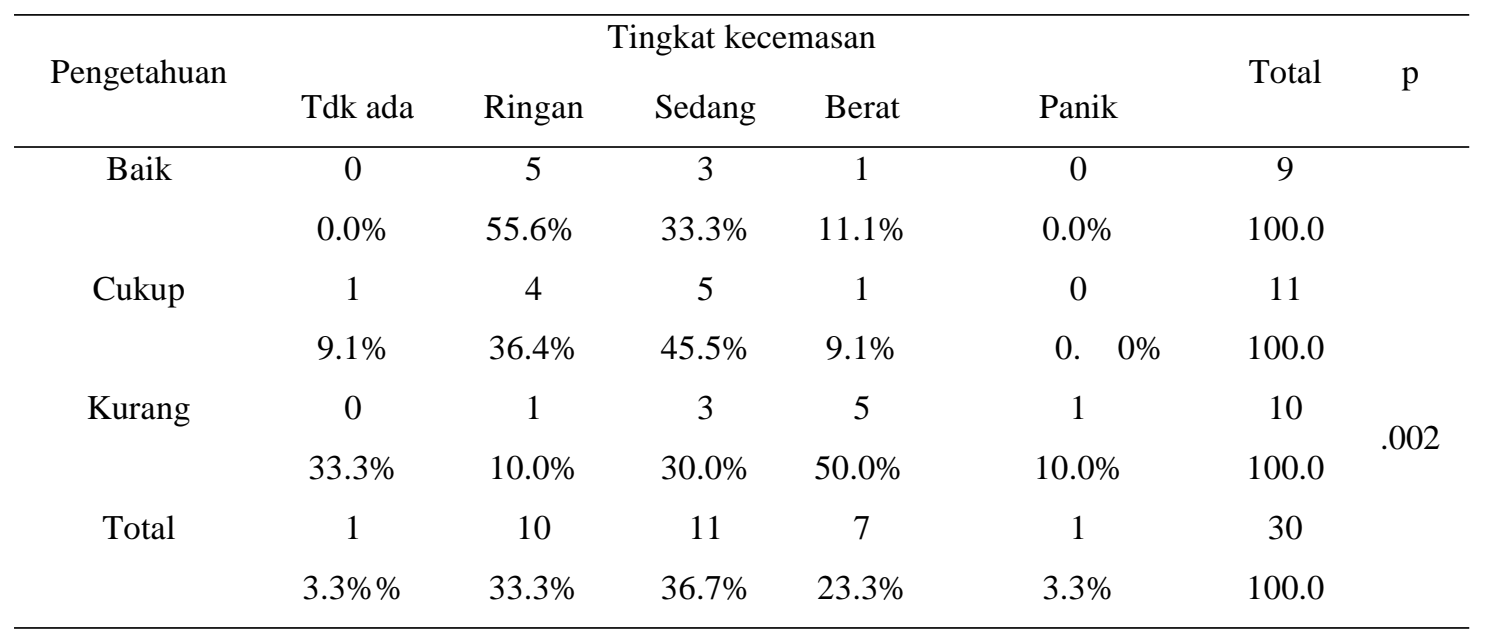

Berdasarkan tabel 7 diketahui bahwa Ibu primigravida dengan sectio caesarea yang berpengetahuan kurang, mengalami tingkat kecemasan berat sebanyak 50.0\%, tingkat kecemasan panik $10.0 \%$. Sedangkan untuk Ibu primigravida yang berpengetahuan baik, mengalami tingkat kecemasan ringan sebanyak $55.6 \%$ dan tingkat kecemasan sedang sebanyak $33.3 \%$. Dari hasil uji statistik Kendal tau C dengan tingkat kepercayaan 95\%, didapatkan hasil $p$ value sebesar 0.002 . Hal ini berarti ada hubungan yang signifikan antara pengetahuan dengan tingkat kecemasan ibu primigravida dengan sectio caesarea di Rumah Sakit X. 
Hasil penelitian ini dikuatkan oleh Dwi Hastuti (2015) di RS Panti Waluyo Surakarta, yang mengemukakan bahwa ada hubungan yang signifikan antara pengetahuan dengan tingkat kecemasan ibu primigravida dengan sectio caesarea, dimana $p$ value $=0.033$.

Menurut Notoadmodjo (2010), pengetahuan merupakan factor dominan yang sangat penting untuk terbentuknya tindakan seseorang. Pengetahuan merupakan pengaruh awal bagi seseorang akan berperilaku. Pengetahuan Ibu tentang sectio caesarea sangatlah penting. Hal ini akan berdampak pada pemeliharaan kehamilan dan pengambilan keputusan persalinan pada akhir kehamilan. Meningkatnya kecenderungan wanita untuk melahirkan dengan operasi berhubungan dengan semakin meningkatnya perhatian mereka tentang kehamilannya (Kasdu, 2009).

Berdasarkan hasil penelitian diatas, peneliti berpendapat bahwa pada Ibu primigravida yang pengetahuannya kurang, cenderung akan mengalami kecemasan sedang hingga dapat menimbulkan panik. Dari hasil penelitian dapat dilihat, bahwa yang berpengetahuan kurang, mengalami kecemasan sedang hingga ada yang panik. Hal ini juga dikuatkan dari hasil kuesioner dimana gejala kecemasan yang dialami responden adalah kecemasan berat yang mencapai 50,0\%. Pengetahuan dapat membentuk keyakinan tertentu sehingga seseorang berperilaku sesuai keyakinan. Hal ini dikuatkan dengan data bahwa Ibu primigravida dengan sectio caesarea yang pendidikannya SMA, mengalami tingkat kecemasan berat sebanyak $42.9 \%$ dan yang mengalami panik $7.1 \%$ sedangkan untuk ibu yang pendidikannya perguruan tinggi, mengalami tingkat kecemasan ringan sebanyak 50.0\%, kecemasan sedang sebanyak $43.8 \%$.

\section{KESIMPULAN DAN SARAN}

Kesimpulan

Dari hasil penelitian didapatkan hasil adanya hubungan bermakna antara pengetahuan dengan tingkat kecemasan ibu primigravida dengan sectio caesarea di RS X ( $p$ value $=0.002)$. Hal ini dapat memberikan masukan bagi petugas kesehatan pentingnya penyuluhan kesehatan/ edukasi bagi ibu-ibu yang hamil mengenai persiapan hamil, apa yang perlu diperhatikan ketika hamil (makanan, kebersihan dsb), dan persiapan ketika akan melahirkan baik 
dengan normal maupun section caesarea.

Saran

Rumah Sakit diharapkan dapat meningkatkan pemberian informasi mengenai persiapan persalinan sectio caesarea kepada ibu hamil.

\section{DAFTAR PUSTAKA}

Astuti, Yanita. (2012). Hubungan Karakteristik Ibu Hamil Primigravida Trimester Ketiga dengan Tingkat Kecemasan di RSUD Pasar Rebo. Universitas Indonesia

Dalami. (2009). Asuhan Keperawatan Jiwa dengan

Ibu Pre Operasi di Ruang Catleya Rumah Sakit Panti Waluyo Surakarta. Stikes Kusuma Husada, Surakarta.

Hawari. D. (2013). M anajemen Cemas dan Depresi. Edisi 2. Jakarta : Balai Penerbit Fakultas Kedokteran Universitas Indonesia.

Hutabalian, D. (2011). Pengaruh Faktor Internal dan Eksternal Ibu Bersalin dalam Persalinan di Rumah Sakit U mum Daerah Swadana Tarutung. Universitas Sumatera Utara, Sumatera Utara.

Indrayani, M. Keb \& Moudy. (2016). U pdate Asuhan Persalinan dan Bayi Baru Lahir. Jakarta : TIM.

Kasdu, Dini. (2008). Solusi Problem Persalinan. Jakarta : Puspa Swara.
Masalah Psikososial. Jakarta : Trans Info Media.

Depkes, RI. (2012). Buku Acuan Persalinan Normal. Jakarta: Depkes RI.

Friedman, M.M. (2011). Keperawatan Keluarga: Teori \& Praktik. Edisi 3. Jakarta: EGC.

Handayani, Reska. (2015). Faktorfaktor yang Berhubungan dengan Tingkat Kecemasan Menjelang Persalinan pada Ibu Primigravida Trimester III di Wilayah Kerja Puskesmas Lubuk Buaya Padang tahun 2012. Ners Jurnal Keperawatan. Volume 11, No.1, Maret 2015: 62-71.

Hastuti, Dwi. (2015). Hubungan Pengetahuan tentang Sectio Caesarea dengan Kecemasan

Manuaba, I.B.G. (2010). Ilmu Kebidanan, penyakit kandungan dan KB untuk pendidikan bidan, edisi 2 . Jakarta: EGC.

Marni dan Margiyati. (2013). Pengantar Psikologi Kebidanan. Yogyakarta: Pustaka Belajar

Mulyawati. (2011). Faktor - faktor yang berhubungan dengan tindakan persalinan melalui operasi sectio caesarea. Ejournal keperawatan Volume 2 nomor 1. http://journalunnes.ac.id/index. php/kemas.

Nolan. M. (2008). Kehamilan dan melahirkan. Jakarta : Arcan.Notoatmodjo, S. (2010). $M$ etode Penelitian Kesehatan. Jakarta : Rineka Cipta. 
Notoatmodjo, S. (2014). IImu Perilaku Kesehatan. Jakarta : Rineka Cipta.

Nursalam. (2009). Konsep dan penerapan Metedologi Penelitian IImu Keperawatan. Jakarta : Salemba Medika.

Novitasari, Trias; Budiningsih,TE; Mabruri, MI. (2013). Keefektivan Konseling Kelompok Pra persalinan untuk menurunkan Tingkat Kecemasan Primigravida menghadapi persalinan. Developmental and Clinical Psychology. Volume 2, No.2.

Oxorn, H \& Forte, W. R. (2010). Ilmu Kebidanan: Patologi \& Fisiologi Persalinan Premature. Yogyakarta : Penerbit ANDIdan Yayasan Essentia Medica.

Nn.Kecemasan Ibu yang Anaknya dirawat RSUP Prof. DR.R.D.Kandou Manado. Jurnal e-Biomedik (eBM). Volume 1,No3.

Sinha, Kounteya. (2010).Article Times Of India. http://timeofindia.indiatimes.co $\mathrm{m} /$ india/caesarian.sectionaccou ntsfor9ofallbirthinindia/articles /1325244. Diakses tgl 8 juni 2017.

Stuart. (2007). Buku Saku Keperawatan Jiwa. Edisi 5. Jakarta. EGC.

Sugiyono. (2008). M etode Penelitian Kuantitatif, Kulitatif, $R \& D$. Bandung: Alfabeta.

Susilo, wilhelmus Hary. (2012). Statistika \& Aplikasi : Untuk Penelitian Ilmu Kesehatan. Jakarta : Trans Info Media.

Susilo, Wilhelmus Hary dan Limakrisna Nandan. (2012). me 1, No1.
Prawirohardjo. S. (2009). IImu Kebidanan. Jakarta : Yayasan Bina Pustaka Sarwono.

Rahman, Abd; Hermiyanti; Gustianti, Nindy. (2016). Role Health Workers Related to Anxiety Level of Third Trimester Pregnant Women in Face the Birth Process in Maternity Room Anutapura Palu General Hospital. International J ournal od Sciences: Basic and Applied Research (IJ SBAR). Volume 29, No.2, pp 268-276.

Rahmi, Laila. (2016). Faktor-faktor yang berhubungan dengan Kekurangan Energi Kronik (KEK) pada ibu hamil di Puskesmas Belimbing Padang. Jurnal Kesehatan Medika Saintika. Volume 8, No.1.

Cermat Menyusun Kuesioner Penelitian Ilmu Keperawatan. Jakarta : Trans Info Media.

Susilo, Wilhelmus Hary dan M. Havidz Aima. (2013). Penelitian dalam Ilmu Keperawatan : Pemahaman dan Penggunaan Metode Kuantitatif Serta Aplikasi dengan Program SPSS dan Lisrel. Jakarta : In Media.

WHO. (2013). World Health Statistics 2013.

Zamriati, Wa Ode; Hutagaol, Esetr; Wowiling, Ferdinan. (2013). Faktor-faktor yang berhubungan dengan Kecemasan Ibu hamil menjelang persalinan di Poli KIA PKM Tuminting. Ejournal Keperawatan (e-Kp). Volu 